\title{
MORPHOLOGICAL IDENTIFICATION OF SCORPION SPECIES FROM JAZAN AND AL-MEDINA AL-MUNAWARA REGIONS, SAUDI ARABIA
}

\author{
AL-ASMARI A. K. (1), AL-SAIF A. A. (2), ABDO N. M. (1)
}

(1) Research Center, Armed Forces Hospital, Riyadh, Saudi Arabia; (2) Department of Medicine, Armed Forces Hospital, Riyadh, Saudi Arabia.

ABSTRACT: The present work is a complementary contribution to the comprehensive study of the scorpion sting syndrome in Saudi Arabia. It deals with the identification and determination of medically important scorpions and the other ones, which were collected from two regions (Jazan and Al-Medina Al-Munawara), based on their morphology (the molecular phylogeny and venom characteristics will appear in subsequent publications). The specimens collected from those two regions were brought to the Research Center laboratories in several batches. Morphological identification of the collected specimens was done employing identification keys. There were 646 specimens collected from Jazan Region. A single species, Nebo hierichonticus (Family Diplocentridae), and five genera with four identified species, Parabuthus liosoma, Hottentotta jayakari (salei?), Compsobuthus werneri, Leiurus quinquestriatus (Vachoniolus globimanus?), Vachoniolus spp. (other species) and Orthochirus innesi (Family Buthidae), were classified as extant scorpions in the region. Three hundred and ninety-six specimens from Al-Medina Al-Munawara Region were categorized into eight groups; four of them were identified. Three buthids, Leiurus quinquestriatus, Androctonus crassicauda, Orthochirus innesi and one scorpion specimen, Scorpio maurus, were identified and classified as extant scorpions in this region. The other four species are still not completely identified. They are Vachoniolus (Buthacus minipectinibus?) globimanus? (Unidentified-1), Compsobuthus spp (arabicus?) (Unidentified-2), Compsobuthus spp (werneri?) (Unidentified-3) and a single specimen of Androctonus spp (australis?) (Unidentified4 ), all of which belong to the family Buthidae.

KEY WORDS: morphology, Parabuthus liosoma, Hottentotta jayakari, Buthidae, Jazan.

CONFLICTS OF INTEREST: There is no conflict.

CORRESPONDENCE TO:

ABDULRAHMAN KHAZIM AL-ASMARI, P.O. BOX: 7897(775S), Riyadh, 11159, Saudi Arabia. Phone: +996-1-4777714, ext. 25100. Fax: +996-1-4786601. Email: akasmari@medu.net.sa or abdulrahman.alasmari@gmail.com. 


\section{INTRODUCTION}

Current literature on scorpion taxonomy recognizes 16 formally valid extant scorpion families (some including extinct genera or species): Bothriuridae, Buthidae, Chactidae, Chaerilidae, Diplocentridae, Euscorpiidae, Hemiscorpiidae, Heteroscorpionidae, Luridae, Liochelidae, Microcharmidae, Pseudochactidae, Scorpionidae, Superstitioniidae, Troglotayosicidae, and Urodacidae (14, 20, 34-36, 44-47, 59).

A decade ago, there were only nine recognized families (56) but the recent increase indicates a considerable activity in high-level (subfamilies and upper) scorpion taxonomy. The result was the discovery of entirely new families such as Pseudochactidae (19); elevating in rank existing subfamilies, such as Euscorpiinae, Superstitioniinae (62), Heteroscorpioninae (33), Hemiscorpiinae and Urodacinae (36, $44)$, and creating new taxa at family rank for genera formerly placed in other families such as Microcharmidae and Troglotayosicidae (33-35).

Rank and single phyla of some newly created families lead to dispute $(36,44-47)$ on family status of Hadogenidae and Lisposomidae. Relevant to the systematics of extant scorpion families is the recent progress in reassessing of existing fossil scorpion taxa and description of new ones. Kjellesvig-Waering (25) revised all fossil scorpions. The majority of which belong to now extinct lineages at the level of suborders and infraorders. This is why especially important are the recent discoveries of Cretaceous orthostern scorpions from Brazil $(5,6)$, Lebanon $(37)$, Burma $(38,54)$, and France (39).

The studies of Prendini and Wheeler (48) summarized the works on classification of recent (extant) scorpions during the past 25 years. Scorpion families were seven (30), the number was raised to $13(61)$, reduced to nine $(43,56)$, reverted to $13(27)$, again raised to $16(14)$, further increased to $20(36)$, then reduced to $14(57)$, raised to $18(48)$ and back to $13(15,58)$. These works were thoroughly analyzed and professionally criticized by Prendini and his colleague Wheeler (48), suggesting that a centralized record of taxa might be the only solution for ensuring quality control in the taxonomy and future publishing. Fet and Soleglad (15) have rejected this criticism and reverted to their previous classification.

Previous scorpion studies and surveys in Arabia (1, 2, 65) confirmed the presence of only two species (Androctonus crassicauda and Leiurus quinquestriatus) in $\mathrm{Al}$ - 
Medina Al-Munawara Region, which belong to the family Buthidae. Other buthid species like Androctonus crassicauda, Buthacus leptochelys and Vachoniolus (Buthacus) minipectinibus were reported from other places in Saudi Arabia (65). In fact, these two species of Al-Medina Al-Munawara Region are the most toxic and hence medically important species $(24,55)$. New synonyms were found in the taxonomy of some families of Old World scorpions (9), but Fet and Braunwalder (10) have tackled the preparation of accurate identification keys dealing with current problems in taxonomy and biogeography of the Eastern Mediterranean area. Some recent studies were provided concerning the scorpion fauna of the Middle East (66).

The family Buthidae, with 48 genera and over 500 species, is the largest and most widespread of the scorpion families $(12,43)$. Its members occupy all six faunal regions, but the greatest generic diversity occurs in the Old World, especially in the Afrotropical Region (22 genera) and in southern portions of the Palaearctic Region (23 genera). Although there have been many attempts to recognize subfamilies in Buthidae, none appears satisfactory (60). However, the interested reader is referred to other sources of information $(4,26,28,31,42,49,68)$, in addition to websites of scorpiology $(3,15,22,67)$.

The family Diplocentridae had been represented by a single species in Saudi Arabia so far, but this family has some features and relationships in common with the family Scorpionidae (43) and now is considered part of it, according to recent arguments of classification (48).

The family Scorpionidae includes seven genera distributed among three subfamilies. Scorpionidae contains some of the world's largest living scorpions. Heterometrus (Gigantometrus) swammerdami reaches lengths up to $16.8 \mathrm{~cm}$ (7), and Pandinus imperator, from 18 to $20 \mathrm{~cm}$ (64). A third species, Opistophthalmus gigas, has been recorded at $16 \mathrm{~cm}$ in length (29). These characters actually represent synapomorphies for the two sister groups Scorpionidae and Diplocentridae.

In fact, several scorpion species are indistinguishable from one another, on morphological grounds. As cryptic species, they could only be verified with chemical or genetic methods $(22,67)$. Diplocentridae, in contrast to scorpionids, possess only the fundamental number of trichobothria, a distinct subaculear tubercle, and venom with a reddish pigment and variable toxicity (22, 50-53). Lourenço (32) retained Hemiscorpiinae in Scorpionidae with doubts that leave this situation pending for 
further phylogenetic studies.

Another newly recorded species in Jazan Region is Hottentotta jayakari (salei?), which was found to belong to Buthidae. Other scorpion species belonging to this genus (Hottentotta jayakari jayakari and Hottentotta jayakari salei) were recorded from Oman (21) and their distribution is extended north to Israel (63) until Turkey (23).

The aims of the present work are to confirm the already reported scorpions as well as to record the newly identified ones in Jazan and Al-Medina Al-Munawara Regions, Saudi Arabia.

\section{MATERIALS AND METHODS}

\section{Scorpions}

Professional hunters, who were specifically recruited for this job, hunted down and collected the scorpions from the wild, infested areas of Jazan and Al-Medina AlMunawara Regions. Jazan Region is on the eastern coast of the Red Sea in the southwest of Saudi Arabia and Al-Medina Al-Munawara Region is in the northwest, not far from the eastern coast of the Red Sea (Figure 1). Scorpion specimens were brought to the Riyadh Military Hospital $(\mathrm{RMH})$, Research Center Laboratories in groups (batches). 


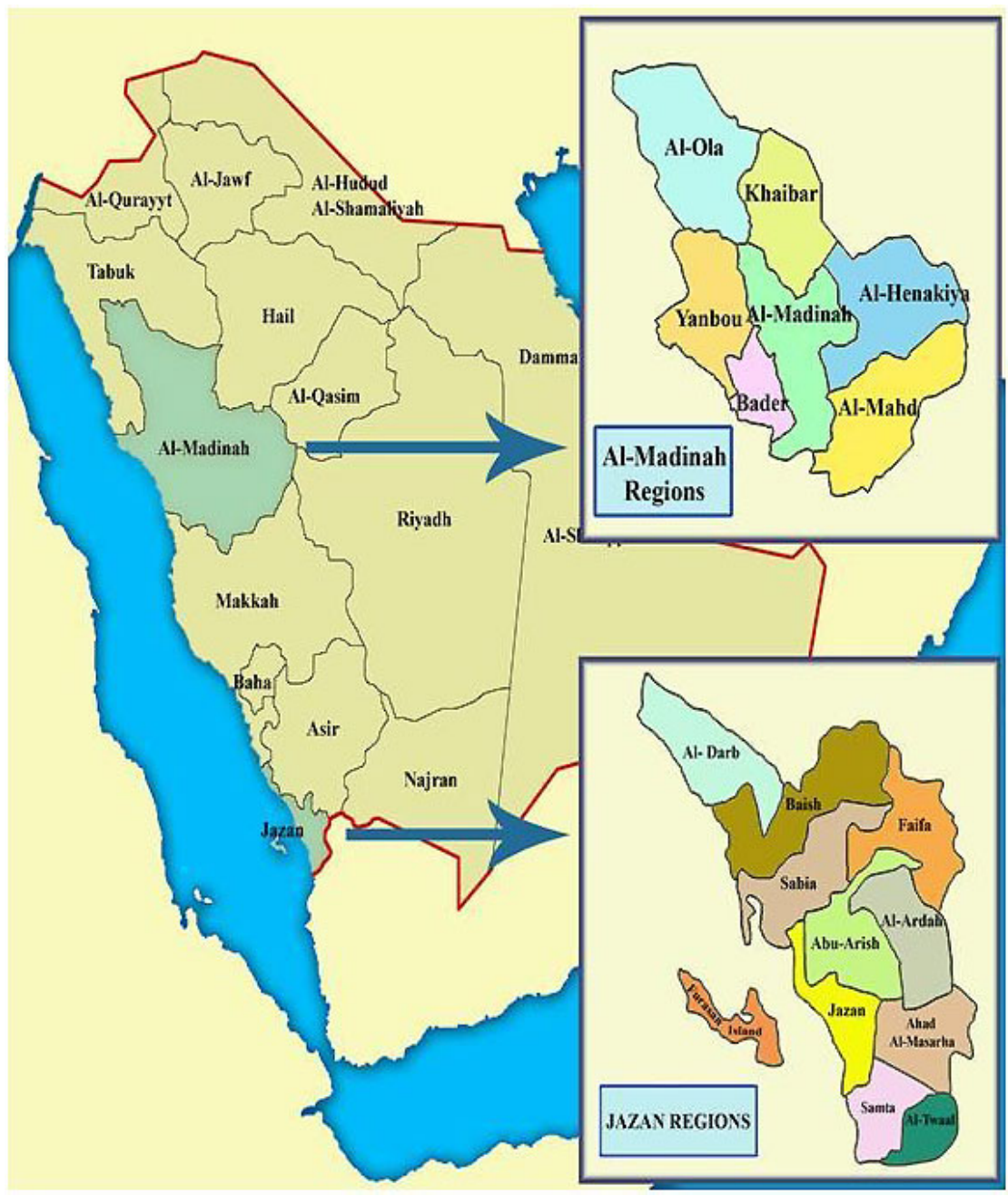

Figure 1 Map of the Kingdom of Saudi Arabia showing the two study areas of Jazan and Al-Medina Al-Munawara Regions (reformed from Saudi Maps).

\section{Maintenance of Living Scorpions and Preservation of Died Scorpions}

Living scorpions were kept in plastic boxes with water ad libitum and fed with mealworms every fortnight. Yellow mealworms were supplied from a local animal facility, raised with the beetle Tenebrio molitor Linnaeus (William, 40, 41). Died scorpions were preserved in $70-96 \%$ ethanol and stored in our laboratory for morphological identification.

\section{Morphological Examination and Diagnosis of Scorpions}

Sub-grouping and crude morphological identification (names) of well-known groups were done visually, based on experience. The full identification and classification attributes of the other unidentified scorpions were done by running the taxonomic keys of Vachon (65) and Polis (43), employing microscopy. More recent reviews and 
online taxonomy were not fully implemented here, due to the ongoing works and arguments tracing this matter.

\section{Diagnosis Key}

Morphological examination of Saudi Arabian scorpion specimens employing identification keys of scorpion families, subfamilies, genera (43) and species (65) were documented by photos, maps and basic trichobothrial patterns. Visual identification was reconfirmed with the employment of these figures. The key, presented by Polis (43) was a modification of that of Francke and Soleglad (17). It deals with the identification of Old and New World scorpion families and genera. The keys of Vachon (65) deal with the same phylogenetical levels (identifying the species and subspecies), but limited to those extant in the Arabian Peninsula. These keys are also reliable in dealing with juvenile scorpions. The trichobothrial patterns $(43,56,65)$ were the backbone in identification (Table 1, Figures 2 and 3), assisted by the employment of light (Stereo zoom dissection) microscopy. 
Table 1. Numbers, basic patterns and nomenclature of scorpion trichobothria and their carinae, indicating their locations on the surfaces of body and limbs. According to Polis (43).

\begin{tabular}{|c|c|c|c|c|c|}
\hline \multirow[t]{2}{*}{ Segment } & \multicolumn{4}{|c|}{ Surface } & \multirow[t]{2}{*}{ Total number } \\
\hline & Dorsal & Ventral & & External & \\
\hline \multicolumn{6}{|c|}{ TYPE A BASIC TRICHOBOTHRIAL PATTERN } \\
\hline Femur & $d_{1}-d_{5}$ & & $i_{1}-i_{4}$ & $e_{1}, e_{2}$ & 11 \\
\hline Patella & $d_{1}-d_{5}$ & & $i$ & $\begin{array}{l}e b_{1}, e b_{2}, e s b_{1}, \\
e s b_{2}, e m, e s t, e t\end{array}$ & 13 \\
\hline Chela manus & & $V_{1}, V_{2}$ & & $\begin{array}{l}e b_{1}-e b_{3}, e s b \\
e s t, \text { et }\end{array}$ & 8 \\
\hline Fixed finger & $d b, d t$ & & it & $e b, e s b, e s t, e t$ & 7 \\
\hline Sub-total & & & & & 39 \\
\hline \multicolumn{6}{|c|}{ TYPE B BASIC TRICHOBOTHRIAL PATTERN } \\
\hline Femur & $d_{1}-d_{4}$ & & $i$ & $e_{1}-e_{4}$ & 9 \\
\hline Patella & $d_{1}, d_{2}$ & $v_{1}-v_{3}$ & id, iv & $\begin{array}{l}e b_{1}, e b_{2}, e s b, e m \\
e s t_{1}, e s t_{2}, e t\end{array}$ & 14 \\
\hline Chela manus & & V & & $e b_{1}-e b_{3}, e s t, e t$ & 6 \\
\hline Fixed finger & $d b, d t$ & & & eb, esb, est, et & 8 \\
\hline Sub-total & & & & & 37 \\
\hline \multicolumn{6}{|c|}{ TYPE C BASIC TRICHOBOTHRIAL PATTERN } \\
\hline Femur & $d$ & & i & e & 3 \\
\hline Patella & $d_{1}, d_{2}$ & $v_{1}-v_{3}$ & $i$ & $\begin{array}{l}e b_{1}-e b_{3}, e s b_{1}, e s b_{2}, e m_{1}, e m_{2} \\
e s t, e t_{1}-e t_{3}\end{array}$ & 19 \\
\hline Chela manus & $d b, d t$ & $v_{1}-v_{4}$ & & $\begin{array}{l}e b_{1}-e b_{3}, e s b \\
e s t, e t_{1}-e t_{5}\end{array}$ & 16 \\
\hline Fixed finger & $d b, d s b, d s t, d t$ & & $i b, i t$ & eb, esb, est, et & 10 \\
\hline Sub-total & & & & & 48 \\
\hline
\end{tabular}

$d$ : dorsal; $i$ : internal; e: external; $b$ : basal; sb: sub basal; $m$ : medial; $v$ : ventral; st: subterminal; $t$ : terminal. 


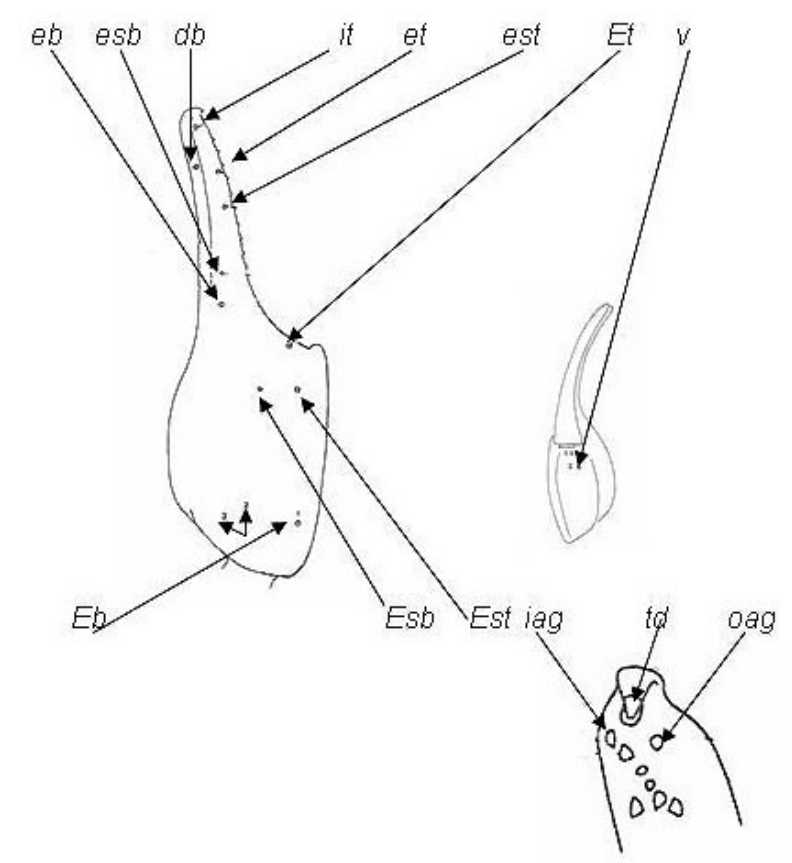

Figure 2 Distinctive distribution and nomenclature of trichobothria on the pedipalpchela of Parabuthus liosoma.

$d$ : dorsal; i: internal; e: external; $b$ : basal; iag: inner accessory granule; oag: outer accessory granule; sb: sub basal; $m$ : medial; $v$ : ventral; st: subterminal; $t$ : terminal; $t d$ : terminal denticle.
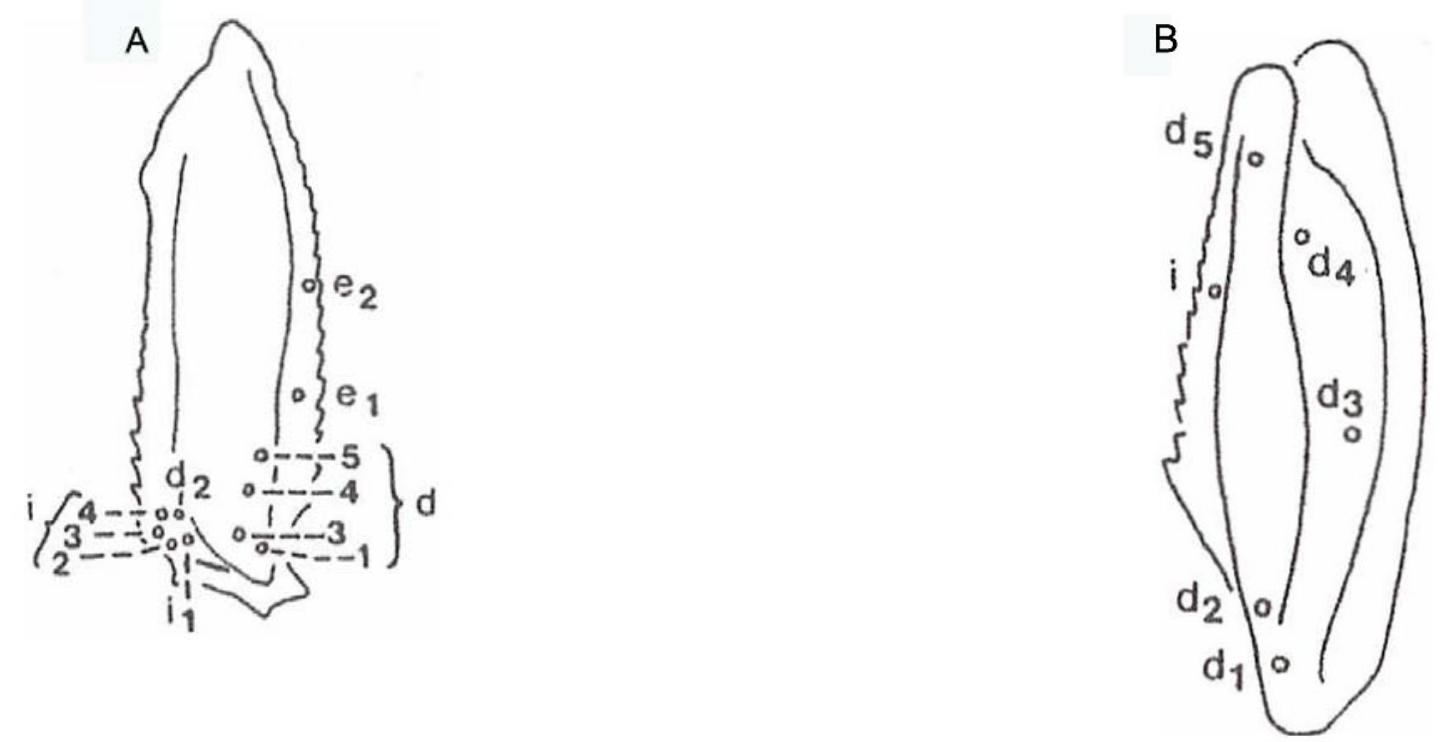

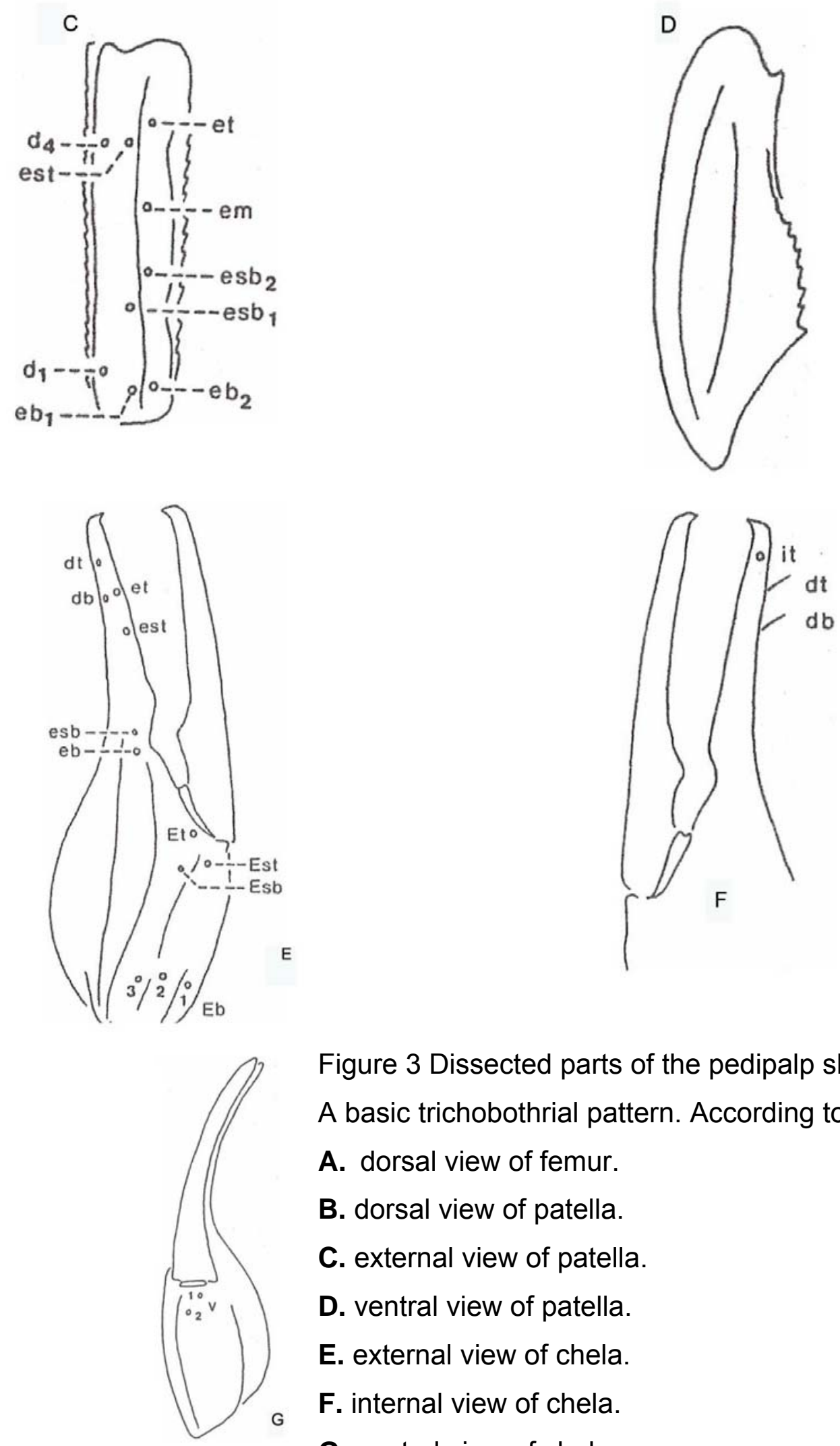

Figure 3 Dissected parts of the pedipalp showing type A basic trichobothrial pattern. According to Sissom (54).

A. dorsal view of femur.

B. dorsal view of patella.

C. external view of patella.

D. ventral view of patella.

E. external view of chela.

F. internal view of chela.

G. ventral view of chela.

$d$ : dorsal; i: internal; e: external; $b$ : basal; sb: sub basal;

$m$ : medial; $v$ : ventral; st: subterminal; $t$ : terminal. 


\section{RESULTS}

\section{Scorpions}

All specimens of scorpions were morphologically divided into groups that resemble each other. Taxonomically, scorpions were categorized into the following higher classification:

Phylum: Arthropoda

Class: Arachnida

Order: Scorpiones (Scorpionida)

\section{Morphological Identification and Diagnosis of Scorpion Genera and Species according to Regions}

\section{Region 1 (Jazan Region):}

Five batches were collected from Jazan Region that gave a total count of 646 specimens of scorpions (Table 2).

Existence of the identified genera (Parabuthus, Hottentotta, Compsobuthus, Orthochirus and Nebo) was reconfirmed by verification of the keys of Sissom (56) and Vachon (65). Species of Nebo and Hottentotta were neither mentioned by Sissom nor by Vachon in these keys. Hence, these two genera were further comparatively verified with the fauna specimens and figures of Oman, which is bordering the region. Nebo hierichonticus and Hottentotta jayakari were recognized, although the latter species demands further verification to the subspecies (salei?). The unidentified groups await further microscopic differentiation, but suggestive names were submitted.

- Identified scorpions in Region 1 (Figures 4A-E):

FAMILY BUTHIDAE KOCH 1837

Genus Parabuthus Pocock, 1890

P. liosoma H. and E., 1828 and 1829 
Genus Hottentotta Birula, 1908

H. jayakari Pocock, 1895

Genus Compsobuthus Vachon, 1949

C. werneri Birula, 1908

Genus Orthochirus Karsch, 1891

O. innesi Simon, 1910

FAMILY DIPLOCENTRIDAE PETERS 1861

Genus Nebo Simon, 1878

N. hierichonticus H. and E., 1828 and 1829

- Unidentified scorpions in Region 1 (Figures $4 \mathrm{~F}$ and $\mathrm{G}$ ):

FAMILY BUTHIDAE KOCH 1837

Unidentified-1

Genus Leiurus? Vachoniolus?

Unidentified-2

Genus Vachoniolus?

V. minipectinibus? globimanus?

Table 2. Scorpions collected from Jazan Region (five batches).

\begin{tabular}{|c|c|c|c|c|c|}
\hline \multirow[t]{2}{*}{ Scorpion Scientific Name } & \multicolumn{2}{|l|}{ Adult } & \multicolumn{2}{|c|}{ Juvenile } & \multirow[t]{2}{*}{ Total } \\
\hline & Alive & Dead & Alive & Dead & \\
\hline Parabuthus liosoma & 122 & 31 & 58 & 33 & 244 \\
\hline Nebo hierichonticus & 44 & 9 & 9 & 7 & 69 \\
\hline Hottentotta jayakari & 70 & 8 & 21 & 10 & 109 \\
\hline Compsobuthus werneri & 39 & 11 & - & - & 50 \\
\hline Orthochirus innesi & 8 & 25 & 4 & 10 & 47 \\
\hline $\begin{array}{l}\text { Leiurus quinquestriatus? } \\
\text { (Vachoniolus globimanus?) }\end{array}$ & 13 & 28 & 3 & 18 & 62 \\
\hline
\end{tabular}


A. K. Al-Asmari et al. MORPHOLOGICAL IDENTIFICATION OF SCORPION SPECIES FROM JAZAN AND ALMEDINA AL-MUNAWARA REGIONS, SAUDI ARABIA. J. Venom. Anim. Toxins incl. Trop. Dis., 2007, 13, 4, p. 832

\begin{tabular}{c|c|c|c|c|c}
\hline Vachoniolus? spp & 7 & 33 & 5 & 20 & 65 \\
\hline Total & 303 & 145 & 100 & 98 & $\mathbf{6 4 6}$ \\
\hline
\end{tabular}

A

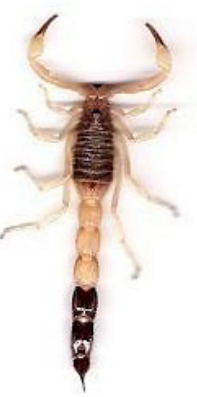

Dorsal

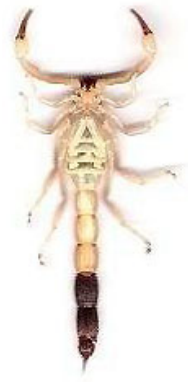

Ventral

C

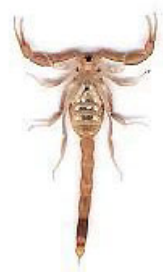

Dorsal

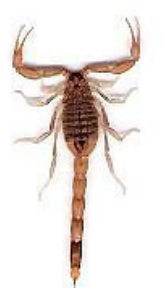

Ventral

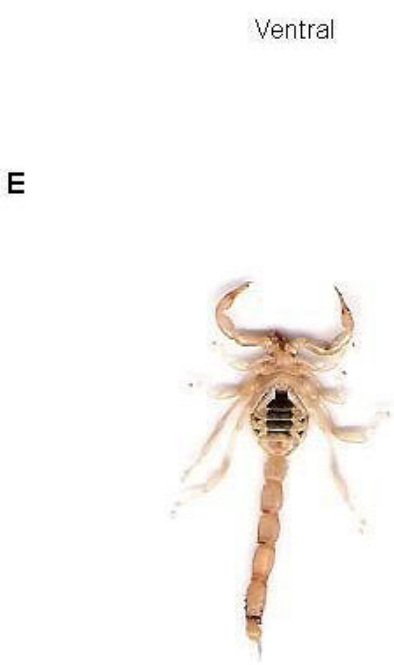

Ventral

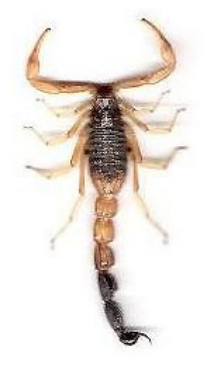

Dorsal

D

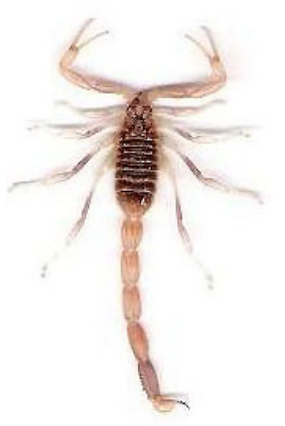

Dorsal

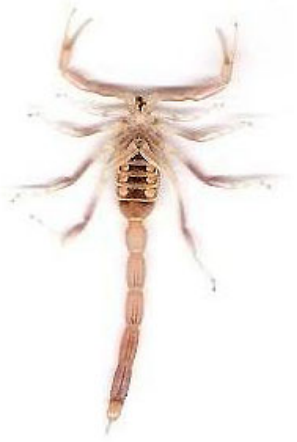

Ventral

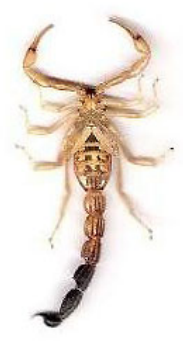

Ventral

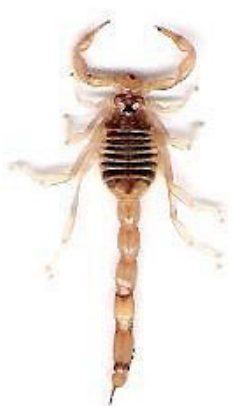

Dorsal

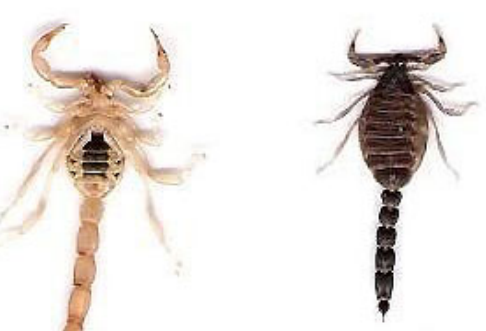

Dorsal 


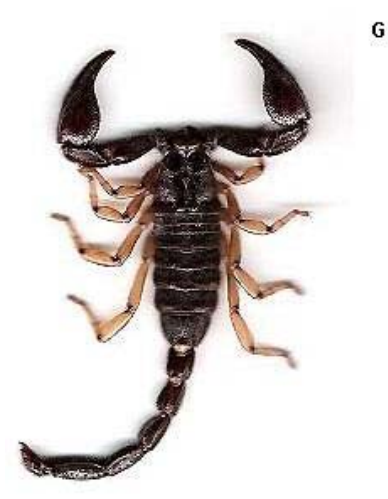

Dorsal

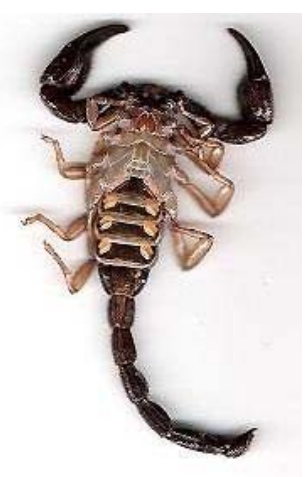

Ventral

Figure 4 Images of all species collected from Jazan Region (dorsal and ventral views).
A. Parabuthus liosoma
B. Hottentotta jayakari
C. Compsobuthus werneri
D. Leiurus quinquestriatus (Vachoniolus globimanus?)
E. Vachoniolus spp.
F. Orthochirus innesi
G. Nebo hierichonticus

\section{Region 2 (Al-Medina Al-Munawara Region):}

There were seven groups in the three collected batches from Al-Medina AlMunawara Region, giving 396 scorpion specimens (Table 3). The existence of four groups was confirmed and they were identified to species according to the keys of Sissom and Vachon $(56,65)$.

- Identified scorpions in Region 2 (Figures 5A-D):

FAMILY BUTHIDAE KOCH, 1837

Genus Leiurus Hemprich and Ehrenberg 1829

Leiurus quinquestriatus Hemprich and Ehrenberg 1828 and 1829

Genus Androctonus Ehrenberg 1828

Androctonus crassicauda Olivier 1807

Genus Orthochirus Karsch, 1891

O. innesi Simon, 1910 
FAMILY SCORPIONIDAE POCOCK, 1893

Genus Scorpio Linne, 1758

Scorpio maurus Linne, 1758

Ssp kruglovi?

- Unidentified scorpions in Region 2 (Figures 5E-H):

FAMILY BUTHIDAE KOCH, 1837

Unidentified-1 (Vachoniolus (Buthacus minipectinibus) globimanus?).

Unidentified-2 (Compsobuthus arabicus?).

Unidentified-3 (Compsobuthus werneri?).

Unidentified-4 (Androctonus australis?)

The four unidentified groups were found to belong to the family Buthidae. Microscopically-aided visual experience and verification of the keys and figures of Vachon (65) were employed. Suggestive taxa were submitted, recalling Vachon's (65) reports of regional distribution. 
A. K. Al-Asmari et al. MORPHOLOGICAL IDENTIFICATION OF SCORPION SPECIES FROM JAZAN AND ALMEDINA AL-MUNAWARA REGIONS, SAUDI ARABIA. J. Venom. Anim. Toxins incl. Trop. Dis., 2007, 13, 4, p. 835

Table 3. Scorpions collected from Al-Medina Al-Munawara Region (three batches).

\begin{tabular}{|c|c|c|c|c|c|}
\hline \multirow[t]{2}{*}{ Scorpion Scientific Name } & \multicolumn{2}{|l|}{ Adult } & \multicolumn{2}{|c|}{ Juvenile } & \multirow[t]{2}{*}{ Total } \\
\hline & Alive & Dead & Alive & Dead & \\
\hline Leiurus quinquestriatus & 134 & 21 & 35 & 21 & 211 \\
\hline Androctonus crassicauda & 80 & 10 & 9 & - & 99 \\
\hline Scorpio maurus & 19 & 30 & - & - & 49 \\
\hline Orthochirus innesi & 3 & - & - & - & 3 \\
\hline Unidentified-1 Vachoniolus globimanus? & 5 & & 5 & - & 10 \\
\hline Unidentified-2 Compsobuthus arabicus? & 17 & 3 & - & - & 20 \\
\hline Unidentified-3 Compsobuthus werneri? & 2 & & 1 & & 3 \\
\hline $\begin{array}{lll}\begin{array}{l}\text { Unidentified-4 } \\
\text { (australis?) }\end{array} & \text { Androctonus } & \text { spp. }\end{array}$ & 1 & - & - & - & 1 \\
\hline Total & 261 & 64 & 50 & 21 & 396 \\
\hline
\end{tabular}

A

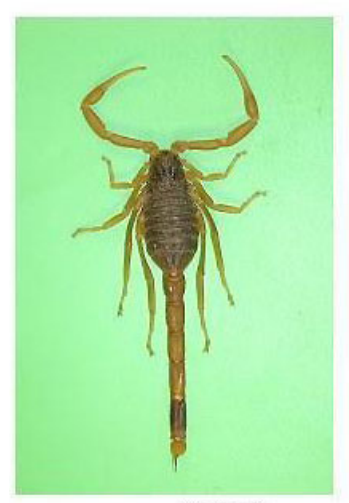

Dorsal

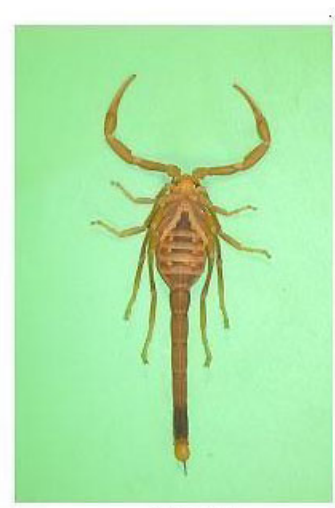

Ventral

B

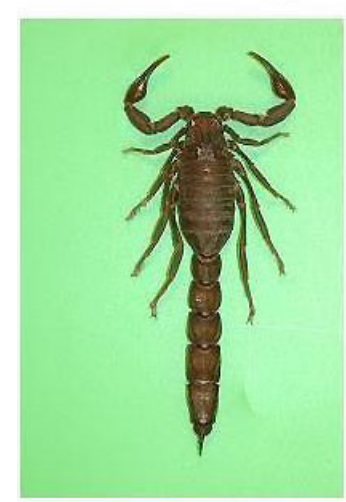

Dorsal

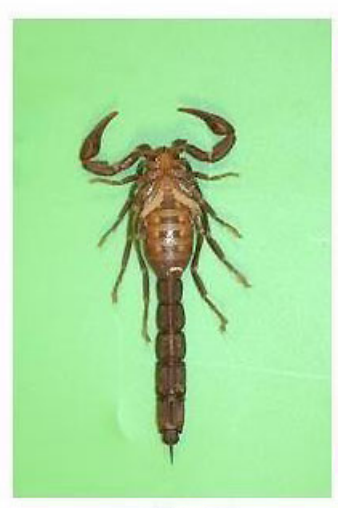

Ventral 
C

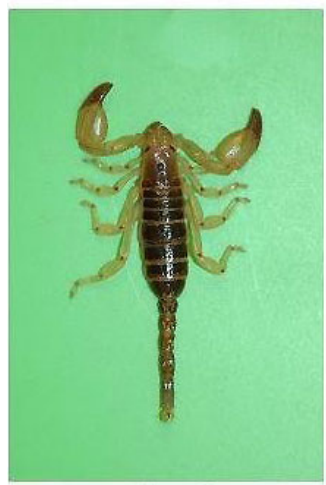

Dorsal

$E$

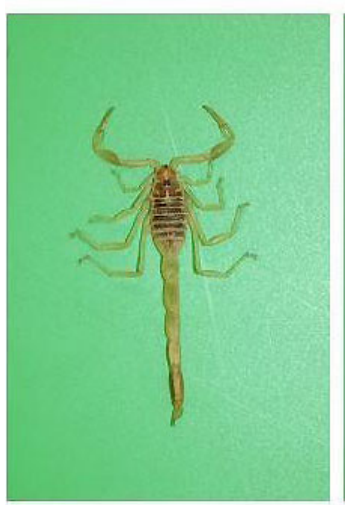

Dorsal

G

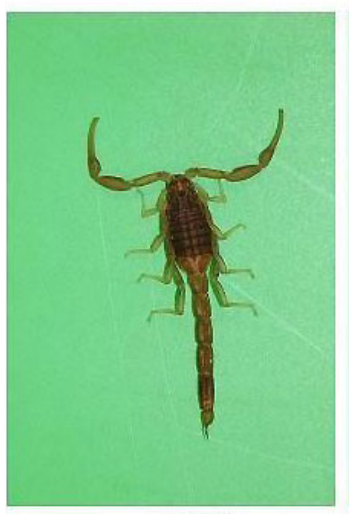

Dorsal

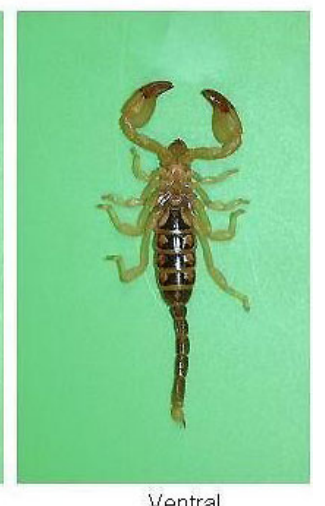

Ventral

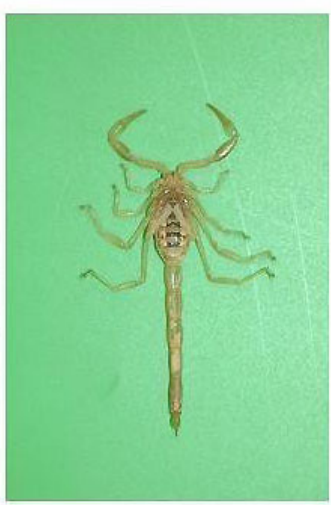

Ventral

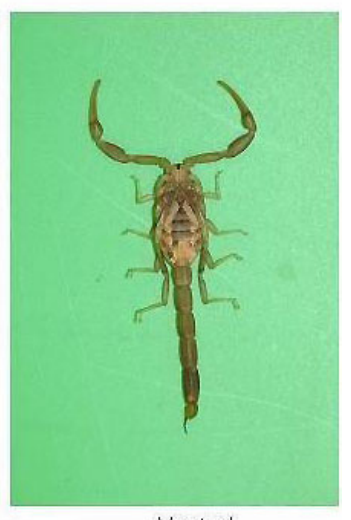

Ventral

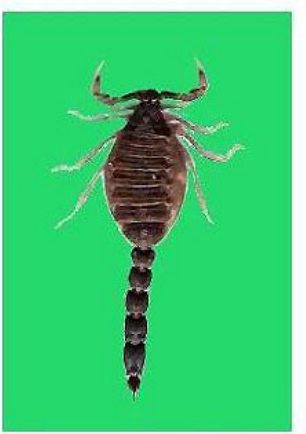

Dorsal

$\mathbf{F}$

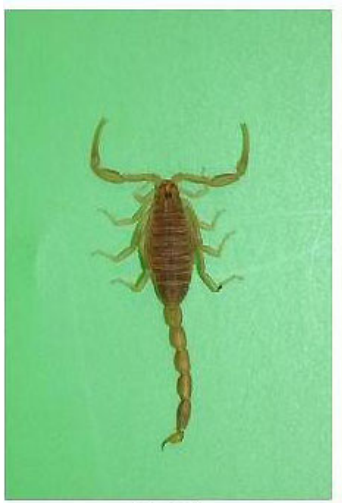

Dorsal

$\mathrm{H}$

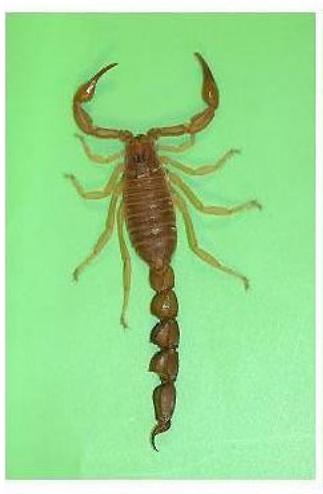

Dorsal

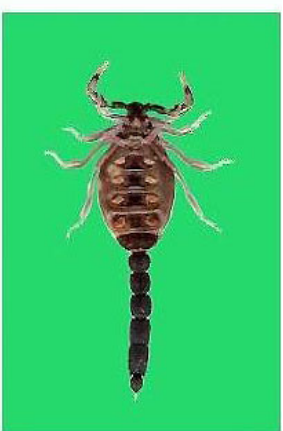

Ventral

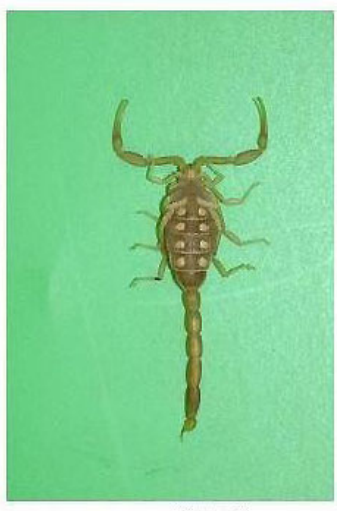

Ventral

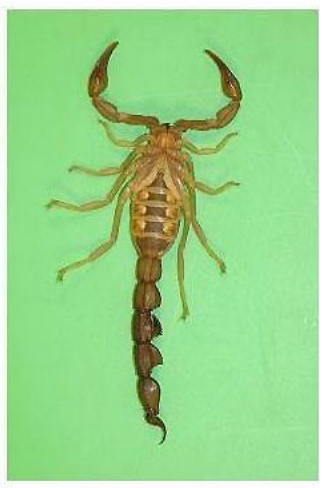

Ventral

Figure 5 Images of all species collected from Al-Medina Al-Munawara Region (dorsal and ventral views).
A. Leiurus quinqestriatus
B. Androctonus crassicauda
C. Scorpio maurus (fuscus?)
D. Orthochirus innesi
E. Unidentified-1 (Vachoniolus (Buthacus minipectinibus) globimanus)
F. Unidentified-2 (Compsobuthus arabicus).
G. Unidentified-3 (Compsobuthus werneri).
$\mathrm{H}$. Unidentified-4 (Androctonus australis?). 


\section{DISCUSSION}

Surveys done in the Arabian Peninsula $(1,2,65)$ confirmed the presence of few species like Parabuthus liosoma and Compsobuthus werneri, which belong to the family Buthidae, in Jazan Region. The collection of other specimens for the first time led to the recognition of Hottentotta jayakari (salei?), which belonged to the family Buthidae, and Nebo hierichonticus, a single species that belonged to the family Diplocentridae. Hottentotta jayakari species has to be confirmed whether it could be a subspecies (salei?). The prominent feature about these species is that they are all weakly venomous (medically unimportant) according to previous reports, although some investigators do consider them medically important (22). As an exception, one doubtful group could be the highly toxic, Leiurus quinquestriatus or Vachoniolus (Buthacus) minipectinibus? globimanus?; however, the latter ones are medically unimportant.

Further studies concerning the toxicity of these groups could be followed up by referring to several authors $(4,13,23,24,26,28,31,42,49,68)$. The present survey confirmed the presence of the two species (Androctonus crassicauda and Leiurus quinquestriatus), which belonged to the family Buthidae in Al-Medina Al-Munawara Region, as they were formerly reported $(1,65)$. Other buthid species like Androctonus crassicauda, Buthacus leptochelys and Vachoniolus (Buthacus) minipectinibus were reported from other places in Saudi Arabia.

The surveys led to the first-time collection and recognition of Scorpio maurus (kruglovi?) which belonged to the family Scorpionidae. This species has to be further verified to subspecies (kruglovi or fuscus).

Androctonus spp. (australis?), which belonged to the family Buthidae, has been a single specimen collected from this region so far, a situation that demands further surveys in this region for confirmation of its existence and species classification. Other completely unidentified specimens, not reported before from this region, were visually examined (based on previous practice and experience) and have to be microscopically confirmed. The four unidentified groups of Al-Medina Al-Munawara Region comprised species that belong to three still doubtful genera. With regard to species verification, they could either be Vachoniolus (Buthacus?) minipectinibus? globimanus? (Unidentified-1), Compsobuthus arabicus? (Unidentified-2), Compsobuthus werneri? (Unidentified-3) or Androctonus australis? (Unidentified-2). 
All these groups belonged to the representative medically important family Buthidae. It is interesting to observe the situation about the combined and overlapped coexistence of species of these two families (Buthidae and Scorpionidae) with regard to their toxicity, according to previous reports $(8,24,55)$. Androctonus crassicauda and Leiurus quinquestriatus, which are considered highly venomous (8), added to Androctonus spp. (australis?), which is considered the most important species in the Old World, are ones of the most toxic scorpions of the world compared with the relatively less toxic and smaller sized ones (22).

Hence, new species are now recognized to be extant in the present surveyed regions, without any previous records, based on the available data submitted by the mentioned investigators. Chronic problems of scorpion classification are now the subject of DNA-based, modern molecular phylogenetic technique applications. These techniques are opening the way for identification methodologies that can deal with the scorpion fauna of the most complicated parts of the world, especially the Eastern Mediterranean and the Middle East $(10,18)$. Prendini and Wheeler (48) have analyzed recent works of the last three decades and proposed solutions for problems of scorpion higher taxonomy and online publishing concerning classification. The molecular data analyses that are combined with the detailed morphological investigations and exhaustive geographic sampling $(10-12,16)$ are dealt with elsewhere in future works.

The preliminary morphological determination of the present survey confirmed the existence of eight species in Al-Medina Al-Munawara and seven species in Jazan Region. Further collections and morphological assessments will be carried out in the next surveys and works to reconfirm the common scorpions endemic in these two regions and the bordering ones.

\section{REFERENCES}

1 AL-HAJJAJ A. Scorpions in the Arab World and rest of the Globe. Amman: Daraldia, 2005. 120p.

2 AL-SADOON M., AL-FARRAJ S. Scorpions, in the Kingdom of Saudi Arabia. Riyadh: Al-Jeraisy, 2000,131p. 
3 ARACHNODATA. [serial on-line], 2006. Available from: http://www.arachnodata.ch/projects.htm. (Braunwalder, M.E., 2005. Scorpiones. Fauna Helvetica 13; 240).

4 BIRULA A. (BYALYNITSKII-BIRULYA AA.). Chlenistobryukhie paukoobraznye Kavkazs-kogo, Kraya [Arthrogastric arachnids of Caucasia]. Part I. Scorpiones. Tiflis: Mémoires du Musée du Caucase, 1917, 5, 1-253. [English translation: Jerusalem: Israel Program for Scientific Translation, 1964].

5 CAMPOS D. Primeiro registro fóssil de Scorpionoidea na Chapada do Araripe (Cretáceo Inferior), Brasil. An. Acad. Bras. Ci., 1986, 58, 1357.

6 CARVALHO MGP., LOURENÇO WR. A new family of fossil scorpions from the Early Cretaceous of Brazil. Comp. Rend. Acad. Sci. Ser. III Sci. Vie., 2001, 332, $711-$ 6.

7 COUZIJN H. Revision of the genus Heterometrus Hemprich and Ehrenberg (Scorpionidae, Arachnidea). Zool. Verhand., 1981, 184, 1-196.

8 DITTRICH K., POWER A., SMITH N. Scorpion sting syndrome - a ten-year experience. Ann. Saudi Med., 1995, 15, 148-55.

9 FET V. Notes on the taxonomy of some Old World scorpions (Scorpiones: Buthidae, Chactidae, Ischnuridae, Scorpionidae). J. Arachnol., 1997, 25, 245-50.

10 FET V., BRAUNWALDER M. The scorpions (Arachnida, Scorpiones) of the Aegean area: current problems in taxonomy and biogeography. Belgian J. Zool., 2000, 130, 17-22.

11 FET V., GANTENBEIN B., KARATAS A., KARATAS A. An extremely low genetic divergence across the range of Euscorpius italicus (Scorpiones: Euscorpiidae). J. Arachnol., 2005, 34, 248-53.

12 FET V., KARATAS A., FET EV., KARATAS A. First data on the molecular phylogeny of Euscorpius (Scorpiones: Euscorpiidae) from Turkey. Entomol. Rev., 2003, 83, 249-52.

13 FET V., LOWE G. Family Buthidae. In: FET V., SISSOM W., LOWE G., BRAUNWALDER M. Eds. Catalog of the Scorpions of the World (1758-1998). New York: The New York Entomological Society, 2000: 54-286.

14 FET V., SISSOM W., LOWE G., BRAUNWALDER M. Catalog of the Scorpions of the World (1758-1998). New York: The New York Entomological Society, 2000, 690p. 
15 FET V., SOLEGLAD M. Contributions to scorpion systematics. I: On recent changes in high-level taxonomy. Euscorpius, 2005, 31, 1-8.

16 FET V., SOLEGLAD M., LOWE G. A new trichobothrial character for the highlevel systematics of Buthoidea (Scorpiones: Buthida). Euscorpius, 2005, 23, 1-40.

17 FRANCKE OF., SOLEGLAD ME. The family Luridae Thorell. J. Arachnol., 1981, 9, 233-58.

18 GANTENBEIN B., FET V., LARGIADER C., SCHOLL A. First DNA phylogeny of the genus Euscorpius Thorell 1876 (Scorpiones, Euscorpiidae) and its bearing on the taxonomy and biogeography of this genus. Biogeographica, 1999, 75, 59-72.

19 GROMOV A. A new family, genus and species of scorpions (Arachnida, Scorpiones) from southern Central Asia. Zoologichesky Zhurnal, 1998, 77, 1003-8.

20 INTERNATIONAL CODE ZOOLOGICAL NOMENCLATURE. Opinion 2037 (cases 3120 and 3120a). Liochelidae Fet and Bechly 1879 (Scorpiones): adopted as a valid substitute name for Ischnuridae Simon 1879 in order to remove homonymy with Ischnurinae Fraser, 1957 (Insecta, Odonata). Bull. Zool. Nomen., 2001, 60, 159-61.

21 IMAGES OF SCORPION SPECIES. Retrieved on 2006. Available from (http://www.ub.ntnu.no/scorpion-files/).

22 ITG LIBRARY. Scorpions. 5.1. Taxonomy. Retrieved on 2006 from (http://lib.itg.be/, last updated on June 14, 2006).

23 KARATAŞ A. New records on the occurrence of Hottentotta saulcyi Simon 1880 (Scorpiones: Buthidae) in Turkey. Israel J. Zool., 2003, 49, 315-6.

24 KARATAS A., COLAK M. Scorpions of Gaziantep Province, Turkey (Arachnida: Scorpiones). Euscorpius, 2005, 30, 1-7.

25 KJELLESVIG-WAERING EN. A restudy of the fossil Scorpionida of the world. Paleontographica Americana, 1986, 55, 287p.

$26 \mathrm{KOCH}$ LE. The taxonomy, geographic distribution and evolutionary radiation of Australo-Papuan scorpions. Rec. West. Aust. Mus., 1977, 5, 83-367.

27 KOVARIK F. Stiri [Scorpions] [in Czeck]. Madagaskar: Jihlava, 1998. 176p.

28 LAMORAL BH. Akentobuthus leleupi, a new genus and species of humicolous scorpion from eastern Zaire representing a new subfamily of Buthidae. Ann. Natal Mus., 1976, 22, 681-91.

29 LAMORAL BH. The scorpions of Namibia (Arachnida, Scorpionida). Ann. Natal Mus., 1979, 23, 498-793. 
30 LAMORAL BH. A reappraisal of the suprageneric classification of recent scorpions and their zoogeography. In: GRUBER J. Ed. Internationaler ArachnologenKongress abgehalten ander Universitat fur Bodenkultur Wien, 8, Verhandlungen, 1980. Proceedings... Vienna: H. Egermann, 1980: 439-44.

31 LEVY G., AMITAI P. Fauna Palaestina Arachnida. I: Scorpiones. Jerusalem: The Israel Academy of Sciences and Humanities, 1980, 130p.

32 LOURENÇO WR. Essai d'interpretation de la distribution du genere Opisthocanthus (Arachnida, Scorpiones, Ischnuridae) dan les region Neotropicale et Afrotropicale Etude taxonomique, biogeographique, evolutive et ecologique. Paris: L'Universite Pierre et Marie Curie, 1985. 287p. [PhD Thesis] .

33 LOURENÇO WR. Faune de Madagascar. 87: Scorpions (Chelicerata, Scorpiones). Paris: Muséum National d'Histoire Naturelle, 1996, 102p.

34 LOURENÇO WR. A new species of Apistobuthus Finnegan, 1932 (Scorpiones, Buthidae) from Iran. Hamburg: Entomologische Mitteilungen aus dem Zoologischen Museum, 1998, 12, 237-44.

35 LOURENÇO WR. Une nouvelle famille est nécessaire pour des microscorpions humicoles de Madagascar et d'Afrique. Paris Ser. Sci. Vie., 1998, 321, 845-8.

36 LOURENÇO WR. Un noveau genre de Scorpion malgache, maillon possible entre les Microcharmidae et les Buthidae. Paris: Comptes Rendus des Séances de l'Académie des Sciences, 2000, 323, 877-81.

37 LOURENÇO WR. Further taxonomic consideration on the Northwestern African species of Buthacus Birula (Scorpiones, Buthidae), and description of two new species. Hamburg: Entomologische Mitteilungen aus dem Zoologischen Museum, 2001, 13, 255-69.

38 LOURENÇO WR. Nouvelles considérations sur la classification et la biogéographie du genre Microbuthus Kraepelin (Scorpions, Buthidae): caracterisation d'une nouvelle sous-espèce pour le Maroc. Biogeographica, 2002, 78, 165-76.

39 LOURENÇO WR. Compléments á la faune de scorpions (Arachnida) de l'Afrique du Nord, avec des considérations sur le genre Buthus Leach, 1815. Rev. Suisse Zool., 2003, 110, 875-912.

40 LYON WF. Rearing mealworms. Classification of the beetle (mealworm insect), ohioline, [serial online], 1991. Retrieved on 2006. Available from: http://ohioline.osu.edu/hyg-fact/2000/2135.html). 
41 LYON WF. Darkling beetle/ Mealworm information. [serial on-line], 1997. Retrieved on 2006. Available from: http://insected.arizona.edu/mealinfo.htm.

42 MELLO-LEITÃO C. Escorpiões sul-americanos. Arq. Mus. Nac., 1945, 40, 7-468.

43 POLIS GA. The biology of Scorpions. Stanford: Stanford University Press, 1990. $587 p$.

44 PRENDINI L. Phylogeny and classification of the superfamily Scorpionoidea Latreille 1802 (Chelicerata, Scorpiones): an exemplar approach. Cladistics, 2000, 16, 1-78.

45 PRENDINI L. Two new species of Hadogenes (Scorpiones, Ischnuridae) from South Africa, with a redescription of Hadogenes bicolor and a discussion of the phylogenetic position of Hadogenes. J. Arachnol., 2001, 29, 146-72.

46 PRENDINI L. A new genus and species of bothriurid scorpion from the Brandberg Massif, Namibia, with a reanalysis of bothriurid phylogeny and a discussion of the phylogenetic position of Lisposoma Lawrence. System. Entomol., 2003, 28, 149-72.

47 PRENDINI L. Revision of the genus Lisposoma Lawrence, 1928 (Scorpiones, Bothriuridae). Insect System. Evol., 2003, 34, 241-64.

48 PRENDINI L., WHEELER W. Scorpion higher phylogeny and classification, taxonomic anarchy, and standards for peer review in online publishing. Cladistics, 2005, 21, 446-94.

49 PROBST P. Zur Fortpflanzungsbiologie und zur Entwicklung der Giftdrüsen beim Skorpion Isometrus maculatus (De Geer, 1778) (Scorpiones, Buthidae). Acta Trop., 1972, 29, 1-87.

50 ROSIN R. A new type of poison gland found in the scorpion Nebo hierichonticus (E. Sim.) (Diplocentridae, Scorpiones). Riv. Parasitol., 1965, 26, 111-22.

51 ROSIN R. Effects of the venom of the scorpion Nebo hierichonticus on white mice, other scorpions and paramecia. Toxicon, 1969, 7, 71-3.

52 ROSIN R. Note on the alpha-hemolytic effect of the venom of the scorpion Nebo hierichonticus. Toxicon, 1969, 6, 225-6.

53 ROSIN R. Paper electrophoresis of the venom of the scorpion Nebo hierichonticus (Diplocentridae). Toxicon, 1973, 11, 107-8.

54 SANTIAGO-BLAY JA., FET V., SOLEGLAD ME., CRAIG PR. A second scorpion specimen from Burmese amber (Arachnida: Scorpiones). J. System. Palaeontol., $2004,2,147-52$. 
55 SIMARD JM., WATT DD. Venoms and toxins. In: POLIS GA. Ed. The Biology of Scorpions. Stanford: Stanford University Press, 1990: 414-44.

56 SISSOM WD. Systematics, biogeography and paleontology. In: POLIS G. Ed. The Biology of Scorpions. Stanford: Stanford University Press, 1990: 64-160.

57 SOLEGLAD ME., FET V. High-level systematics and phylogeny of the extant scorpions (Scorpiones: Orthosterni). Euscorpius, 2003, 11, 1-175.

58 SOLEGLAD ME., FET V., KOVARIK F. The systematic position of the scorpion genera Heteroscorpion Birula, 1903 and Urodacus Peters, 1861 (Scorpiones: Scorpionoidea). Euscorpius, 2005, 20, 1-38.

59 SOLEGLAD ME., SISSOM WD. Phylogeny of the family Euscorpiidae Laurie, 1896: a major revision. In: FET V., SELDEN PA. Eds. Scorpions. In Memoriam Gary A. Polis. British Arachnological Society. Burnham Beeches: Bucks, 2001: 25-111.

60 STAHNKE HL. A key to the genera of Buthidae (Scorpionida). Entomol. News, 1972, 83, 121-33.

61 STOCKWELL S. Revision of the phylogeny and higher classification of scorpions (Chelicerata). Berkeley, University of Berkeley, 1989, 319p. [PhD Thesis]

62 STOCKWELL S. Systematic observations on North American Scorpionida with a key and checklist of the families and genera. J. Med. Entomol., 1992, 29, 407-22.

63 THE SCORPION FAUNA. Scorpions of Oman. [serial on-line], 2006. Available from: http://perso.orange.fr/eycb/scorpions/AIOman.htm.

64 VACHON M. Sur la répartition du grand Scorpion noir des îles de la mer Égée: Jurus dufoureius (Brullé). Rev. Gén. Sci. Pur. Appliq., 1953, 60, 96-100.

65 VACHON M. Arachnids of Saudi Arabia, Scorpiones. Fauna of Saudi Arabia, 1979, 1, 30-66.

66 VIGNOLI V., KOVAŘíK F., CRUCITTI P. Scorpiofauna of Kashan (Esfahan Province, Iran) (Arachnida: Scorpiones). Euscorpius, 2003, 9, 1-7.

67 WALTER REED BIOSYSTEMATICS UNIT. Scorpion identification page. [serial on-line]. $\quad$ Retrieved 2006.2 Available from: (http://wrbu.si.edu/scorpions/sc phylogeny.html .

68 WERNER F. Scorpiones, Pedipalpi. In: BRONNS H. Ed. Klassen und Ordnungen des Tierreichs. Leipzig: Akademische Verlaggesellschaft, 1934: 1-316. 